
\title{
Analysis of Factors Affecting House Ownership in Indonesia
}

\author{
Taufik Hendra Kusuma \\ willy.arafah@gmail.com
}

Abstract: This study aims to analyze the variables that significantly and effectively affect the policy of house ownership in an effort to increase the house ownership in Indonesia. The research used Tawhidi String Relationship (TSR) methodology with circular causation through simultaneous equations as a quantitative analysis tool. Variables that are expected to affect the house ownership are 1) Sharia Financing, 2) Commercial Funding Cost, 3) House Sale Price, 4) Consumer Confidence, 5) Home Business Tendency, 6) Number of Houses Available and 7) Housing Infrastructure.This study uses secondary data sourced from Bank Indonesia, Financial Services Authority, Central Bureau of Statistics, Ministry of PUPR and some other supporting data from institutions and companies. The data used is monthly panel data from January 2005 to December 2016. The research method used is quantitative method with simultaneous equation analysis to see the causal relationship between the variables with Two Stages Least Square model (2SLS). The hioptesis test used at 95\% significance level. The results show that Shariah Financing, Commercial Funding Costs, Business Tendencies, Number of Houses Available and Infrastructure House affect each other positively and significantly the Number of House Ownership. On the other hand, although it is theoretically influential, the House Sale Price and Consumer Confidence do not affect the House ownership. Based on the results of the study, it is suggested to the Government and the stakeholders of housing to focus on the creation of policies involving significant and positive variables affecting the house ownership. The limitation of this research is that this research is only done from quantitative perspective, does not use certain weight on each variable and not done quantitative simulation for more effective house ownership policy.

Keywords: housing, backlog, developer, house, house habitable, financing, cost of funds, business tendency, infrastructure, price, consumer confidence, Tapera.

\section{INTRODUCTION}

The house is a building that functions as a residence or shelter and means of family development (Law of the Republic of Indonesia No. 4 of 1992 on Housing and Settlements). One measure to assess the adequacy of the provision of a habitable home is to calculate the number of habitable house (house ownership) or lack of adequate housing that has not been able to be fulfilled by the Government and the private sector. The Ministry of Public Housing (Kemenpera) and the Central Bureau of Statistics (BPS) use the term backlog (shortage) of the house, namely the shortage of houses inhabited by households as one of the main indicators of housing provision. In the realm of property, the term home backlog is defined as the gap between the number of houses built by the number of homes needed. There is a different use of the term backlog between Kemenpera and BPS. In the perspective of BPS, home backlog occurs on the lack of house ownership while in perspective Kemenpera, backlog is a shortage of habitable home. For the purposes of this study, the definition of the home backlog used refers to the definitions used by BPS. In this study, the backlog is indirectly measured as opposed to House ownership. Variable used is house ownership.

Prayitno (2012) states that the pace of housing shortage for low income communities in Indonesia each year averages around 900,000 units with an average home supply capacity of 200,000 units per year resulting in a backlog of 700,000 units per year. The percentage of families who do not own homes is high and implicitly implies the home backlog data. This condition is exacerbated by data that as many as $23 \%$ of urban residents 
live in slums. UN Habitat (2008) data shows that Indonesians living in urban areas reach 121 million (52\%) and $26 \%$ of them inhabit slum areas. Various efforts are made by the Government to improve the provision of houses, including the policy of Subsidized KPR in 2007 to meet the needs of low-income households to own homes, flats for housing programs (rusunami), self-help housing policies (stimulant programs aimed at improving the quality of housing habitable housing program), the Government's Program of Liquidity Program (FLPP) program that allows Low-Income Communities (MBRs) to own a small-scale home or rusunami property with light installments and a fixed rate of 7.25\%. Related to FLPP, Residential Property Price Survey by Bank Indonesia (2016) shows that total FLPP fund disbursements from 2012 to 2016 amounted to 387,658 units with total value of Rp24.7 trillion. This condition is far behind the growth rate of home backlog which reaches 700,000 units per year house. To cover the shortage of FLPP funds, the Government will also provide KPR Difference Installment (Interest Rate Subsidy) and Advance Payment to assist civil servants through Bapertarum. Another policy program launched by the Government in 2014 to address the backlog of homes is the Million House Program, the program is similar to the one-billion National Housing Development (GNPSR) program that was carried out in 2003. In addition, several other policies are revisions to 10 legislation, (2015), setting interest rates on mortgage loan of FLPP at $5 \%$ per annum with a maximum loan term of 20 years, and $1 \%$ mortgage loan program applicable to users of KPR FLPP facility with low-income community priorities (MBR), first home purchase, and especially rusunami by Bank Tabungan Negara (2014).

However, these programs do not automatically resolve national backlog issues. The problem of backlog of housing is mutually influential with the limited land for the fulfillment of housing development needs. Ritohardoyo (2015) states that factors of land constraints, marginalization of local communities, environmental degradation due to housing construction, financing constraints and lack of institutional ambiguity are the cause of national backlog of houses. This condition is in line with the research of Amir, Salle and Nur (2014) which states that high backlog numbers occur due to limited availability of land for housing. Researchers concluded that the role of Local Government through the implementation of the activities of land bank (land bank) as a form of provision of land in the field of people's settlement becomes a significant factor, either for the needs of the property or residential property tread. Lasmarohana (2015) study that the purchasing power factor, particularly related to Bank Indonesia's Loan to Value (LTV) policy in acquiring mortgages in banks is a significant factor in the acquisition of houses by the community. This variable becomes the most influential factor on the decision of the mortgage because it can improve the prudential aspects of the bank in providing mortgage. The Murbaintoro et al (2009) study suggests that the development of vertical shelter in a city still requires the role of government (central, provincial and municipal) synergistically to be able to help low-income and low-income people in the form of housing assistance / subsidies.

From the above explanation, it can be concluded that the backlog of houses - as antithesis of house ownership - is a problem faced by the Government today. Various analyzes and policies have been presented but until now the problem of house ownership is still relatively an unfinished problem that becomes the background of research. This study will focus on studying the relationship of housing variables with the variable of house ownership. This study is based on the Tawhidi String Relationship (TSR) mindset. Based on this framework, the research analysis generally contains the process of interaction, integration and evolution of human knowledge (shuratic process) which is practically a relationship analysis of research variables to see the interrelationship between variables. The relationship between these variables is a process of circular causation which is a repetitive analysis in the framework of the learning process (learning process) towards the solution of a better research problem. Based on the above background, the formulation of the research problem are: 1) Is there any influence between the variable of House Ownership and variable 1) Sharia Financing, 2) Commercial Funding Cost, 3) House Sale Price, 4) Consumer Confidence, 5) Home Business Tendency ,6) Number of Houses Available and 7) Housing Infrastructure? and 2) What is the effective policy to increase house ownership? 


\section{LITERATURE REVIEW}

The nature of housing not only covers the house from the physical side of the building, but covers all the supporting facilities either inside or outside, for example environmental safety system, drainage system, roads, power grid, telephone network etc. (Hidayati, 2001). The house is basically divided into 2 types namely the tread house (landed house) and high rise (high rise). The apartment unit (Sarusun) is an apartment unit whose main purpose is used separately with main function as shelter and has means of connecting to public road. Based on the above understanding, the term "house or" habitable house "used in this study refers to the definition of Physical Building according to BPS standards, which is a minimum area of $10 \mathrm{~m} 2$ and the building has walls, floors and roofs, both used for residence and not a place to stay.

Nsengiyumva \& Tati (2017) examines the factors that contribute to homeownership among migrant women and the difference between metropolitan and non-metropolitan areas in South Africa. The study used regression analysis with Community Survey 2007 data from Statitika South Africa. Age factors, length of stay, house type and house size are factors that contribute to house ownership among migrant women. Studies also show that women migrants in non-metropolitan areas are more likely to have a home than a metropolitan migrant. Ulyana, Daryanto and Saptono (2016) examined the relationship between credit demand and home purchase. The methodology of correlational analysis of the variables that affect the purchase of a home. The fall in demand for housing loans will also have an impact on home purchase decisions on credit. The results suggest that although normatively interest is prohibited in the practice of sharia banking, but sharia financing is highly correlated and sensitive to changes in interest rates. Kamal et.al (2016) examines the factors affecting house prices from a developer perspective in Malaysia. The methods used are online and face-to-face surveys. The results showed that location, macroeconomic, demographic, land and industrial zones were the main factors affecting house prices.

Hilber and Vermeulen (2015) conducted a study to find out whether house prices have a correlation to changes in income. His research of quantitative methodology uses panel data on 353 Local Planning Authorities in the UK for the period 1974-2008. As a result, Government policy has a positive impact on the price elasticity of houses, especially in urban areas. House price volatility is positively correlated with consumption and macroeconomic stability. Zandi et.al (2015) examines the economic factors affecting house prices in Penang, Malaysia. The study used data from 2007 to 2014. The results showed that Loan Interest Rates and GDP were the main factors affecting property prices in Penang. Prasetyo (2014) examines the monetary policy (interest rate) of Bank Indonesia on mortgage interest The results show that changes in the BI Rate affect deposit rates and lending rates of banks. Isamil et al (2014) examines the factors that influence the selection of KPR Syariah by adult workers in Malaysia. The sample is 160 workers at 1 institution. The results of his research stated that reputation factor, service quality, religiosity, media advertising and social influence are the main factors influencing the selection of sharia banks. Ondola, et.al (2013) conducted an analysis of the Government's housing ownership policy in the provision of houses in Kisumu, Kenya. Variables used are cheap housing loans, land tenure status, drinking water source infrastructure, home building materials, suitability of buildings for disabled people, and whether or not discrimination exists. Quantitative research methods with surveys, questionnaires, and secondary data, using multiple linear regression. The results of this study suggest that housing policy is not the focus of the Government as evidenced by the lack of effective subsistence policy, the promotion of land tenure and inadequate infrastructure. Governments should use a bottom-up approach in which the user community should be involved.

Jiboye, Adesoji David (2011) analyzed housing policies in Nigeria. The research focuses on creating an analysis of housing policies for sustainable development (sustainable debvelopment). The results of his research indicate the need for a review of current policies with variable economic capacity of the community, the cost of housing construction, loan interest rates, land prices, per capita income and other supporting economic factors. Majale, 
Tipple, and French (2011) conducted a study to determine the correlation between mortgage to demand and home supply using quantitative methodology. The study was conducted in Asian countries. The results suggest that flexible long-term mortgage shortages limit the supply and demand of homes, so most mortgages (marked by large advances and high interest rates) are only enjoyed by high-income people. Arnott, Richard (2008) looks at differences in housing policies in developed and developing countries. Research focuses on differences in housing policies in developing and developed countries. In general, the housing policy under study is the same, that is by moving the housing market and Government support to the informal sector for developing countries. Efficiency in housing policies in developing countries can be achieved by enabling formal and informal sector market mechanisms. Government-backed housing policies for the poor are required. Benjaminsen and Dyb (2008) conducted a housing policy analysis for homeless people in Scandinavian countries. The research variables include house price policy, housing provision and housing facility. The results of his research indicate that the large number of public housing stocks does not guarantee easy access to homeless community ownership. Other variables to be considered are the availability of houses, adequate housing facilities and housing prices. Cruz (2008) conducted a study to determine the relationship between home financing and ease of acquisition of a home. Quantitative methodology. The research was conducted in Hongkong, Malaysia, Singapore, Japan, Taiwan, China, Thailand, Indonesia, South Korea and Philippines. The results of his research indicate that the research variables include the study of the property market, transaction costs, slums and the ability of house ownership and the ease of home financing is very helpful acquisition of housing units. Linggi, Rita Kalla (2005) analyzed the comparative housing policy during the New Order and the transition in Indonesia. The results showed that the research variables are the licensing of housing and the amount of housing. During the New Order period, the housing policy was centralized and carried out forcibly on the grounds of the common interest of demolition and forced evictions. The transitional housing policy is carried out with decentralization where local and municipal governments are given responsibility for the management of public housing, while the central government functions as facilitator, coordinator and supervisor. Soelaksana (2000) conducted a correlation analysis of residential business and variable purchasing power. The results of his research indicate that the problems that affect the housing business include the decline in ability / purchasing power of the people and high interest rates on credit.

Abraham and Hendershott(1996) conducted a study to find the relationship between house prices and household income using a quantitative methodology. The study was conducted in 30 cities in the United States during the years 1972-1992. The research variables are house price, real income (real income). The results of his research indicate that house prices and household income are mutually cointegrated over the long term. Angel, Mayo and Stephens (1993) developed indicators to assess cross-country housing policies quantitatively through surveys in 52 countries, including Indonesia (Jakarta). Variables used are price, number of house supply, number of house demand, quality and quantity of rumah.Hasil research indicates there are 10 housing indicators that can be criteria of housing policy, namely: 1) house price to income ratio and 2) rent to income ratio price indicator), 3) housing production and 4) housing investment (quantity indicator), 5) floor area per person, 6) permanent structures, 7) unauthorized housing, 8) housing credit portfolio (indicator of demand), 9 ) land development multiplier, and 10) infrastrucrure expenditures per capita (supply indicator). Mehta, Meera and Mehta (1991) conducted a study to determine the relationship between mortgage and home offer. Qualitative methodology. The study was conducted in India, by reviewing the relationship of mortgages and home offerings. The results of his research indicate that although home financing (mortgage) increases but supply on the number of homes can not keep up, so house prices rise. A more flexible housing funding model is required

\section{RESEARCH MeTHOdology}

The simultaneous equation method with Two Stage Least Square (2SLS) was used in this study. Population in this research is Government, developer of housing and stakeholders that directly or indirectly involved in implementation of house ownership policy. This study uses population data in the form of secondary data, ie 
Analysis of Factors Affecting House Ownership in Indonesia

data contained in Bank Indonesia, Central Bureau of Statistics, Ministry of Public Works and Public Housing (PUPR), Perum Perumnas and other secondary data sources. The sample data of this study was conducted in the period of 2005 to 2016 on a monthly basis with data sources from the Reports of Bank Indonesia, Financial Services Authority, Central Bureau of Statistics, monthly and annual reports of the Ministry of PUPR, annual reports Ministry of Finance, annual reports of State Owned Enterprises and secondary data others. Based on this, the number of data per variable is 144 samples per variable.

\section{RESULT AND DISCUSSION}

Recapitulation of test results is given in Table 1 below. These results indicate the relationship of independent variables of House ownership as a criterion variable with other variables are as follows:

Table1. Simultaneous Test Results of Housing Variables with House ownership

\begin{tabular}{|l|c|c|c|c|}
\hline Variable & Coefficient & Std. Error & t-Statistic & Prob. \\
\hline Constanta & 1.410872 & 0.240522 & 5.865870 & 0.0000 \\
\hline Sharia Financing & 0.057151 & 0.024539 & 2.328927 & 0.0213 \\
\hline Commercial Funding Cost & 0.279455 & 0.059100 & 4.728525 & 0.0000 \\
\hline House Sales Price & -0.068176 & 0.063723 & -1.069889 & 0.2866 \\
\hline Consumer Confidence & -0.027857 & 0.029581 & -0.941725 & 0.3480 \\
\hline Home Business Tendency & -0.163899 & 0.042355 & -3.869647 & 0.0002 \\
\hline Number of Houses Available & $2.09 \mathrm{E}-01$ & $3.72 \mathrm{E}-02$ & 5.608537 & 0.0000 \\
\hline Hosuing Infrstructure & $-2.04 \mathrm{E}-01$ & $4.14 \mathrm{E}-02$ & -4.940517 & 0.0000 \\
\hline R-squared & 0.932001 & Mean dependent var & & 1.687007 \\
\hline Adjusted R-squared & 0.928501 & S.D. dependent var & & 0.027931 \\
\hline S.E. of regression & 0.007468 & Sum squared resid & & 0.007586 \\
\hline F-statistic & 266.2888 & Durbin-Watson stat & & $1.15 \mathrm{E}-01$ \\
\hline Prob(F-statistic) & 0 & Second-Stage SSR & & $7.59 \mathrm{E}-03$ \\
\hline
\end{tabular}

Source: The analysis was processed in 2018

Based on the result of coefficient of determination doubled known that value of R-Square equal to 0,932001 so that can be explained that set of predictor variable can explain variable equal to $93.2001 \%$ where the rest explained by other variable. Standard Error (S.E. of regression) value of 0.007468 is smaller than S.D. dependent $\operatorname{var}(0.027931)$, so the model is valid. From the simultaneous test of F-statistic, it is known that p-value $(0)<0.05$ so that the simultaneous test results conclude receive Ha and free variable simultaneously affect the variable of House Ownership. The hypothesis conclusion of the relationship between the predictor variables above to the Variables of Ownership House is explained in Table 2.

Table. 2 Conclusion of the Hypothesis Testing

\begin{tabular}{|c|l|c|}
\hline \multicolumn{2}{|c|}{ Hyphothesis } & Result \\
\hline H1 & Sharia financing affects House Ownership & Accepted \\
\hline H2 & Cost of commercial funds affects House Ownership & Accepted \\
\hline H3 & House Sale Price affects House Ownership & Rejected \\
\hline H4 & Consumer Confidence affects House Ownership & Rejected \\
\hline H5 & Household Business Tendency affects House Ownership & Accepted \\
\hline H6 & Number of Available Homes affects House Ownership & Accepted \\
\hline H7 & Housing Infrastructure affects House Ownership & Accepted \\
\hline
\end{tabular}

Source: Summary result of analysis and data processing, 2018 
The results of the study generally indicate that the variables of Shari'a Financing, Commercial Funding Costs, Home Business Tendencies, Number of Houses Available and Housing Infrastructure each affect each other Variables Ownership House.The linkages between Shariah Financing and House ownership variables are in line with Mehta, Meera and Mehta (1991), Majale, Tipple and French (2011), Cruz (2008), Ullyana, Daryanto and Saptono (2016) and Lisnawati (2015) results. Mehta's research, Meera and Mehta (1991) suggest the need for more flexible housing finance models to increase house ownership as well as a correlative correlation between mortgages and housing offerings, whereby home finance significantly affects house ownership. The research of Majale, Tipple and French (2011) and Cruz (2008) essentially confirms that home finance greatly assists house ownership. Ullyana, Daryanto and Saptono (2016) also stated that there is a long-term relationship between macroenomy variables, property prices and sharia and conventional home financing. Lisnawati (2015) states that development budgets and financing schemes are a significant factor for addressing backlog issues, at least gradually. The difference between conventional and syariah financing lies in the contract used. Conventional financing is principally borrowed by borrowing with interest as a variable. The concept of sharia financing emphasizes that profits (in the form of margins) can not be ascertained at the earliest as conventional financing. In sharia financing, the parties (debtor and creditor) in the agreement bear the risk (loss sharing) so that the concept of risk in shariah financing is distributed to economic actors.

Although sharia financing portfolio in Indonesia is still very small compared to commercial bank financing (4.8\%) but the growth of sharia financing compared to commercial banks that climbed from $2 \%$ in 2004 to $5.7 \%$ in 2016 indicates that the level of consumer confidence in sharia financing is increasing. Structurally, one of the factors driving the above increase is the existence of several legislative products that provide legal certainty and increase the activity of syariah financial markets, such as Law No.21 of 2008 on Sharia Banking, Law No.19 of 2008 on State Sharia Securities (Sukuk) and Law no. 42 of 2009 on the Third Amendment of Law no. 8 of 1983 on VAT Goods and Services. The issuance of Sharia Banking Law encourages an increase in the number of Sharia Commercial Banks from 5 to 11 in less than 2 years (2009-2010). However, the issue of concern regarding shariah financing is that although sharia financing continues to increase but the percentage is still very far compared to commercial banks. Secondly, the percentage of non performing financing of sharia financing is higher than that of general financing. This requires the attention of practitioners of sharia financing for the real role of sharia financing increasingly visible.

The relation between variable of Commercial Fund Cost and Variable of Ownership of House in line with result of research of Jiboye, Adesoji, David (2011), Majale, Tipple and French (2011), SMF Research Team (2016), Zandi et.al (2015), Prasetya (2014) and (Haryono, 1999). Jiboye, Adesoji, David (2011) analyzed the efforts to create a housing policy for sustainable development in which one of the significant factors affecting the creation of housing policy is the interest rate on loans. Majale, Tipple and French (2011) show that one of the factors that makes mortgage distribution (house ownership) only enjoyed by high income people is high interest rates. This is in line with the results of the study. The results of this study are also in line with a study conducted by the SMF Research Team (2016) which shows that the inflation and base rate variables significantly affect the proportion of home purchases on credit. Zandi et.al's (2015) study shows that Loan Interest Rates and GDP are the main factors affecting property prices and ownership. Prasetya (2014) stated that the change in Bank Indonesia Interest Rate affected deposit interest rate and bank credit interest rate which resulted in decreasing demand for housing loans due to high mortgage rates (Haryono, 1999).

The decline in the cost of funds in the long term and its effect on house ownership is also in line with Ullyana, Daryanto and Saptono (2016) studies, although normatively interest is prohibited in sharia banking practices, but the results show that sharia financing is linked and sensitive to change reference rate. Some sharia financing institutions make interest rates a benchmark of financing margins. Generally the reason for benchmarking is that the total cost charged to consumers remains competitive. In the contract of sale and purchase, the imposition of this margin is part of the sale and purchase transactions that can be done with the principle 
of likes and agreements of the parties. This is in line with Ibn Taymiyyah's opinion, which states that thaman al mithl (equivalent price) is determined by market mechanisms that run freely-competitive and undistorted between supply and demand (P3EI UII, 2008: 331), where prices will vary according to quality of the buyer of the goods.

The variable of house selling price and House Ownership variable do not affect each other. The results of this study differ from the results of research conducted by Benjaminsen and Dyb (2008) and Angel, Mayo and Stephens (1993) which concluded that house prices are one of the factors of house ownership. On the contrary, the results of this study are in accordance with Ondola, et.al (2013) results which conclude that house price variables (through subsidized policies) are not effective in the context of house ownership as housing policies are not the focus of the government. One of the programs that can represent the pattern of restriction on the selling price of the house and its sales effect to the public is the Housing Financing Liquidity Facility program (FLPP). FLPP is a government-made program to help low-income people access home mortgages (KPR). This program is implemented by the Ministry of Public Works and People's Housing with the standard price of maximum and certain house. KPR FLPP has low interest rates and small and fixed installments throughout the loan period. The results of this study are in harmony with Purwanti (2012) stating that the constraints faced in the provision of housing with FLPP is the synchronization of programs conducted with each other and the lack of coordination done by one agency with other agencies. Marpaung (2012) states that although FLPP policy generally works well, there is a minimum policy of $36 \mathrm{~m} 2$ (Act No. 1 of 2011), maximum KPR welfare area and selling price not exceeding Rp 70 million (PMK No. 31 in 2011) to make the price of homes sold increased so that the absorption of the market.

In the context of the selling price of the house (as a basic necessity), the backlog of homes that tend to be high (although down in recent years) is a form of increasing population and demand but not compounded by price reductions. The role of the Government in protecting the selling price is done one of them doing FLPP program. However, the FLPP program has not significantly increased the number of homeowners. This is confirmed in Marpaung's (2012) study which states that FLPP policy has not been able to balance the housing demand gap (backlog) due to lack of supply compared to home needs. Although the results of this study indicate that the variable selling price of the house has no effect on house ownership, factors causing the inequality of this variable more to other housing support factors that resulted in the determination of the selling price of the house is not effective in overcoming the problem of house ownership. This is reinforced by the test results that show a correlative relationship between the variable selling price of houses and home financing variables.

Consumer confidence variable in this research is indicated by indicator of Consumer Confidence Index (IKK). IKK is an economic indicator that seeks to know and measure how much optimism consumers to economic conditions that are generally expressed in savings and shopping activities The results showed that the variable of consumer confidence and house ownership variables do not affect each other. The results of this study are in line with the results of research by Benjamines and Dyb (2008) stating that house ownership (marked with public housing stock) is not related to consumer confidence to own a home. Consumer confidence also has no correlation to house ownership due to a housing policy that is not aligned to the real estate industry according to research Linggi (2005). The results of this study differ from Arnott's research, Richard (2008) which states that the efficiency of housing policy can be achieved by activating the formal and informal sector market mechanism so that it can not directly increase consumer confidence in the fulfillment of the needs of the house. This study implies that the variable of house ownership has a correlation to consumer confidence. Ondola et.al (2013) in the study also states that the relationship of house ownership and consumer confidence does not occur due to ineffective housing policy. In the micro-order, consumer confidence arises also due to consumer confidence in the producer's safety. In the context of house ownership, consumer confidence to buy a house depends on the level of security of the developer in the homework that generally concerns about the timeliness of delivery of home (delivery) and the suitability of home specifications in accordance with previous 
agreements. In a shuratic process, consumer confidence should have a positive correlational relationship with house ownership. The existence of a process of home sales by developers to buyers who run well and trust in the long term will increase the level of consumer confidence in the cost of spending to the housing sector. If this condition does not go well, the shuratic process cycle needs to be re-examined for the reasons why this ideal concept is not working, including other variables that have the potential to affect the non-achievement of this correlational condition.

The results showed that Business Tendency variables and House Ownership variables affect each other. The linkage between Business Tendency variables and House Ownership variables is in line with Arnott's (2008), Jiboye (2011), Hilber and Vereule (2015) and Soelaksana (2000) studies. Business tends to be essentially information about the state of business and the economy in the short term, which is in the current quarter and the prediction of the next quarter. The results of Arnott's (2008) study emphasize the importance of efficiency of housing policies as the basis for creating a favorable business climate that ultimately creates a positive business tendency. Furthermore, this study underscores the importance of formal and informal sector activation to support the business climate. Jiboye's research (2011) which emphasizes the importance of business tendency as an effort to create housing policy for sustainable development is also in line with the results of this research. Hilber and Vereule (2015) also show a similar trend, where business tendencies as the output of government policies have a positive impact on consumption, macroeconomic and house ownership. The research is also in line with Soelaksana (2000) research which concludes that the problems affecting housing business are the decreasing of people's purchasing power which is one of the indicators of business tendency and high loan interest rate. The business tendency is related to the developer's projection of the future housing business prospects. In the Islamic context, this business prospect should not only depend on the prospect of material gain but further a form of religious implementation. A profitable business is not only by doing the right measure and the right scales, but also by avoiding all forms and dirty and corrupt cheating practices as revealed in Surah Al A'raaf verse 85 and Surah Al Israa 'verse 35. Qur'an emphasizes that a small business through the halal and thayyib (good) way, is much better than big business done in a haram and khabits (ugly) way.

The linkages between the variable Number of Available Homes and House ownership are in line with Mehta, Meera and Mehta (1991), Angel, Mayo and Stephens (1993), Green (1996), Benjaminsen and Dyb (2008) and Eckert (1990) studies. Mehta's results Meera and Mehta (1991) suggest a relation between the number of house offerings (home available) and house ownership, where the lack of home offerings leads to rising house prices. This research is also in line with the results of the research of Angel, Mayo and Stephens (1993) which states that the indicator of housing production (the number of houses produced or available) is one indicator that affects housing policy in the framework of house ownership. This research is also in line with Green research (1996) which states that limited supply / supply of land will result in the need for housing difficult to meet, especially for low-income groups. However, this study differs from the results of research by Benjaminsen and Dyb (2008) which states that the amount of public housing inventory does not guarantee changes in house ownership. This is as a result of existing housing policies. This conclusion is indirectly in line with research Eckert (1990) which states that the factors that affect the housing market demand are economic factors, social factors, government factors, and environmental factors. In the current context of house ownership, circumcision conditions tend not to occur. This is due to the lack of demand for home (backlog) in certain segments, the level of competition and the length of the home financing process so holding home sales will only increase the cost of funds and lower profits.

The results showed that between housing Infrastructure variables and House Ownership have interrelated relationships. The linkages between housing and house ownership variables are in line with Ondola et.al (2013), Benjaminsen and Dyb (2008), Angel, Mayo and Stephens (1993) and Nsengiyumva \& Tati (2017) studies. The results of research Ondola et.al (2013) mentions infrastructure as one element that affects the effectiveness of house ownership. Infrastructure (facilities) houses are also a variable that affects the house ownership according to Benjaminsen and Dyb (2008). Angel, Mayo and Stephens (1993) also mentioned the variable of expenditures 
per capita infrastructure as one of the influential variables that became the policy of house ownership. The results of this study indirectly in line with the results of research Nsengiyumva \& Tati (2017) stating the factors of age, length of stay, type of house and size of the house is a factor-factors that contribute to house ownership. Although it does not directly mention the above factors as part of the Infrastructure of the house, but the type and size of the house is part of the home infrastructure. The availability of adequate infrastructure is recognized as one of the factors driving regional growth, while increasing the value of land and surrounding properties. The importance of infrastructure development is also felt and experienced by the developers. In the medium to long term, housing infrastructure drives the value of land, property and the surrounding environment more dynamically and stimulates other economic activities.

Islamic economic system necessitates a country to manage all its wealth so as to be able to build the infrastructure needed for the public good. With the management of public property (milkiyyah 'ammah) and state property (milkiyyah daulah) is good, then the source of infrastructure investment funds can be funded from the ability of own capital. The results of this study are in accordance with the design of regional governance within the historical state of the Caliphate where the infrastructure is built in such a way that it reduces transportation needs. The focus on housing infrastructure is also in line with the policy of Islamic development in the time of Rasulullah SAW. This policy began by building the mosque as a place for various activities. Building a mosque has a high priority because it is a means to build and strengthen the creed and morals with various functions. The construction of this mosque is part of the provision of housing infrastructure. The provision of infrastructure as the main variable of homeownership is in line with the practices that have been made during the Caliph Umar bin Khattab, Utsamn ibn Affan, Daulah Umaiyyah (132-656 H / 749-1258 AD) and the reign of Sultan Abdul Hamid II, Sultan Muhammad I , Sultan Nuruddin Muhammad Zanky, Caliph Al Hakim ibn Amrillah and others, where the construction of road facilities, canals, wells, public buildings, dams and others is done (Rais, 2002).

\section{CONCLUSION}

Shari'a Financing Variables, Commercial Funding Costs, Business Tendencies, Number of Houses Available and House Infrastructure affect each other positively and significantly with Household Variables, while other variables (House Sale Price and Consumer Confidence) theoretically affect house ownership but based on empirical evidence in this study did not have a positive and significant effect on the Variables of House ownership.

Effective house ownership policies should focus on efforts to optimize the variables that significantly affect the increase in House ownership. Efforts to issue a policy without regard to factors that effectively increase House ownership will only incur additional costs that do not have a backlog down effect. Factors influencing or influenced by House ownership in this study, can be considered for other parties outside the Government and developers through the implementation of better implementation of house ownership policies.

The variables contained in the TSR Thinking Framework are all endogenous variables that affect each other due to the process of circular causation. In the TSR concept, these variables are variables that have an effect of continuous improvement (continuous improvement) in the increase of House ownership. The shuratic process over the above process arises from the interaction between continuous variables. Through interaction emerges integration as a sign of a consensus followed by evolutionary and maslahah processes in the form of the most efficient and continuous homeownership pattern until sustainability / maslahah is achieved.

\section{REFERENCES}

Abraham, J.M. dan Hendershott, P. H. (1996). Bubbles in Metropolitan Housing Markets, Journal of Housing Research, 7(2), pp. 191-208.

Agrawal, P. (2000). Urban Land Consolidation: a Review of policy and Procedures in Indonesia and Other Asian Countries. GeoJournal 49, March 2000.

Al-Qardhawi, Yusuf. (2007). Fikih Maqashid Syari'ah. Jakarta: Pustaka al-Kautsar.

American Research Journal of Business and Management

Page 9 
Analysis of Factors Affecting House Ownership in Indonesia

Amir, Herni, Salle, Aminuddin, Nur, Sri S. (2014). Kegiatan Bank Tanah Sebagai Bentuk Penyediaan Tanah Untuk Permukiman Rakyat. Analisis, Juni 2014, Vol.3 No.1 pp 29-36.

Angel, Shlomo; Mayo, Stephen K., Stephens Jr, William L. (1993). The Housing Indicators Program: A Report on Progress and Plans for The Future, Neth. J. of Housing and the Built Environment, Vol. 8 No. 1.

Arnott, Richard. (2008). Housing Policy in Developing Countries: The Importance of The Informal Economy, Department of Economics, University of California, Riverside, January 21, 2008.

Basuki, Sulistiyo. (2006). Metode Penelitian. Jakarta: Wedatama Widya Sastra.

Badan Pusat Statistik. (2014). Indonesia Dalam Angka. Jakarta: Badan Pusat Statitik.

Benjaminsen, Lars dan Dyb, Evelyn. (2008). The Effectiveness of Homeless Policies - Variations among the Scandinavian Countries, European Journal of Homelessness, Volume 2, December 2008.

Boonyabancha, Somsook. (2005). Baan Mancong: Going to Scale with "Slum” and Squatter Upgrading in Thailand. Journal of Environment dan Urbanization, Vol 17 No. 1 April 2005.

Bramantyo. (2012). Efektivitas Regulasi Perumahan Di Indonesia dalam Mendukung Penyediaan Rumah Bagi Masyarakat Berpenghasilan Rendah (MBR). Widyariset, Vol. 15 No.1, April 2012.

Capozza, D.R., Hendershott, P.H., Mack, C. dan Mayer, C. J. (2002). Determinants of Real House Price Dynamics. NBER Working Papers 9262, National Bureau of Economic Research, Inc.

Choudhury, M.A. (2014). Islamic Political Economy: An Epistemological Approach. Social Epistemology Review and Reply Collective 3, no. 11 (2014), pp 53103.

Choudhury, M.A. (1992). The Principles of Islamic Political Economy: AMethodological Inquiry. London: Macmillan.

Choudhury, M.A. (2008). Islamic Economics and Finance: Where Do They Stand?. International Journal of Accounting and Finance 02/2008; 1(2), pp. 149-167.

Choudhury, M.A. (2009, Oktober). Islamic Perspective of Sosioeconomic Development. Paper dipresentasikan pada The 6th Biannual Conference in Islamic Economics dan Finance, Tarbiat Modares University, Tehran, Iran.

Cruz, PC.R. (2008). Transaction Costs and Housing Affordability in Asia, International Real Estate Review, Vol. 11 No. 1 , pp. 128-150.

Chiquier, L., dan Lea, M. (Eds). (2009). Housing Finance Policy in Emerging Markets. Washington, DC: World Bank.

Chow, Gregoiry C dan Niu, Linlin. (2014). Housing Price in Urban China as Determined by Demand and Supply. New Jersey: Princeton University (unpublished).

Drakakis-Smith, D. (1979). Low Cost Housing Provision in the Third World. Baltimore and London: The Johns Hopkins University Press.

Doling, John, Vandenberg, Paul dan Tolentino, Jade. (2013). Housing and Housing Finance - A Review of the Links to Economic Development and Poverty Reduction. ADB Economics Working Paper Series, No. 362, August 2013.

Gallin, Joshua. (2003, April). The Long-Run Relationship between House Prices and Income: Evidence from Local Housing Markets. Paper dipresentasikan pada seminar Federal Reserve Board di University of Georgia, AS.

Giddens, Anthony. (1995). The Constitution of Society: The Outline of the Theory of Structuration. Cambridge: Polity Press Cambridge.

Green K, Richard \& Hendershott, Patrick H. (1996). "Age, Housing Demand and Real House”.

Grindle, S. Merilee dan John, Thomas W. (1991). Public Choices and Policy Change: Political Economy of Reform in Developing Countries. Ondon: The John Hopkins University Press.

American Research Journal of Business and Management

Page 10 
Analysis of Factors Affecting House Ownership in Indonesia

Hilber, C.A.L dan Vermeulen, Wouter. (2015). The Impact of Supply Constraints on House Price in England. The Economic Journal, Volume 29 Juni 2015.

Haizhen Wen, Allen C. Goodman. (2013). Relationship between Urban Land Price and Housing Price: Evidence from 21 Provincial Capitals in China. Journal Habitat International 40 (2013), pp. 9-17.

Housing, Tyrner J. (1991). Towards Autonomy in Building Enviroment. London: Marion Boyars Publisher Ltd.

Irawan, Willy, et.al. (2008). Pembangunan Perumahan dan Permukiman di Indonesia. Jakarta: Direktorat Permukiman dan Perumahan Kementerian Negara Perencanaan dan Pembangunan Nasional/BAPPENAS.

Ismail, Shafinar; Azmi, Farah \& Thurasamy, Ramayah. Selection Criteria for Islamic Home Financing in Malaysia. International Journal of Business and Society, Vol. 15 No. 1, 2014, 97 - 110.

Linggi, R.K. (2005). Analisis Tentang Perbandingan Kebijakan Perumahan di Indonesia, Jurnal Teknologi \& Manajemen Informatika, Volume 3 Nomor 3, Malang, Desember 2005.

Majale, M., G. Tipple, dan French, M. (2011). Affordable Land and Housing in Asia: Volume 2. United Nations Human Settlement Program (UN-HABITAT), Nairobi: Union Publishing Services.

McCue, Daniel dan Belsky, Eric S. (2007). Why Do House Prices Fall? Perspectives on the Historical Drivers of Large Nominal House Price Declines. Joint Center for Housing Studies Harvard University W07-3 June 2007.

Mehta, Meera, dan Dinesh Mehta. (1991). Housing Finance System and Urban Poor. Economic and Political Weekly XXVI $(17,1)$, pp.110.

Jiboye, A.D. (2011). Sustainable Urbanization: Issues and Challenges for Effective Urban Governance in Nigeria, Journal of Sustainable Development 4(6), Canada, November 2011.

Kamal, Ernawati Mustafa; Hassan, Hasnanywati; Osmadi, Atasya. (2016). Factors Influencing the Housing Price: Developers' Perspective. World Academy of Science, Engineering and Technology International Journal of Humanities and Social Sciences Vol:10, No:5, 2016.

Kantor, Paula dan Nair, Padmaja. (2003). Risk and Responses Among the Urban Poor in India. Journal of International Development, J.Int. Dev. 15, pp. 957-967.

Kim, Ju Hyung dan Kim, Jaejun. (2010). Relationship Between Demand-Supply in the Housing Market $\quad a \quad n \quad d$ Unsold New Housing Stocks. Journal of Asian Architecture and Building Engineering, November 2010.

Kementerian Pekerjaan Umum dan Perumahan Rakyat. (2015). Kebijakan dan Strategi Penyediaan Rumah Tahun Anggaran 2015-2019. Jakarta: Kementerian Pekerjaan Umum dan Perumahan Rakyat.

Keith, M. Henderson. (2001). Urban Service Delivery in Developing Countries. The International Journal of Public Sector Management, Vol 14. No 4.

Kurniawati, Herlina. (2008). Studi Faktor-Faktor yang Mempengaruhi Prefrensi Penghuni Rumah Susun Pekunden untuk Tetap Tinggal. Universitas Diponegoro. Unpublished.

Lasmarohana, Dona Nove. (2015). Analisis Pengaruh Loan to Value, Jangka Waktu Kredit, Tingkat Pendapatan dan Jumlah Tanggungan Keluarga dalam Keputusan Pemberian Kredit Pemilikan Rumah (Studi Kasus PT Bank Pembangunan Daerah Jawa Timur Cabang Malang). Universitas Brawijaya. Unpublished.

Lisnawati. (2015). Kebijakan Anggaran dan Skema Pembiayaan daalm Mengatasi Backlog Perumahan. Info Singkat Ekonomi dan Kebijakan Publik Vol. VII No. 14/II/P3DI/Juli/2015 pp 13-16.

Malpezzi, S. (1990). Urban Housing and Financial Markets: Some International Comparisons. Urban Studies 27(6), pp. 971-1022.

Marpaung, Martin D.R. (2012). Efektivitas Implementasi Kebijakan Fasilitas Likuiditas Pembiayaan Perumahan (FLPP) untuk Pemilikan Rumah Sejahtera Tapak di Kabupaten Bekasi. Universitas Indonesia. Unpublished. 
Analysis of Factors Affecting House Ownership in Indonesia

Morakinyo, Kolawole Opeyemi, et.al. (2014). An Assessment of Housing Infrastructural Provision in Public Housing: A Case Study of Bashorun Housing Estate Akobo. Civil and Environmental Research Vol.6, No.12, 2014.

Murbaintoro, Ma'arif, Sutjahjo dan Saleh. (2009). Model Pengembangan Hunian Vertikal Menuju Pembangunan Perumahan Berkelanjutan. Jurnal Permukiman Vol. 4 No. 2 September 2009 pp 72-87.

Nsengiyumva, Philomene \& Tati, Gabriel. (2017). Housing Ownership among Female Migrants in South Africa: The Case of Metropolitan and Non-Metropolitan Areas. African Population Studies Vol. 31 No.1, 2017.

Ondola, S.O., Odundo P. dan Rambo, C. M. (2013). Effectiveness of Housing Policies and Their Implementation Strategies in The Provision of Low-Cost Housing to The Urban Poor in Kisumu City, Kenya. International Journal of Academic Research in Progressive education and Development 4(2) pp.1-14.

Ondola, S.O. (2014). Constraints in Housing Policy towards Provision of Low-CostHousing to the Urban Poor in Kisumu City, Kenya, International Journal of Humanities and Social Science Invention, Volume 3, Issue 1, January 2014, pp.31-42.

Perpres 67/2005 tanggal 9 Nopember 2005 tentang Kerjasama Pemerintah dengan Badan Usaha dalam Penyediaan Infrastruktur

Prayitno, Budi. (2013). Konsolidasi Kebijakan Nasional Perumahan Rakyat (online). Tersedia di http:// pusperkimugm.org/home/2013/02/konsolidasi-kebijakan-nasional-perumahan-rakyat-part-1/

Ritohardoyo.(2015). Di Indonesia Backlog Terus Meningkat. Tersedia di http://ugm.ac.id/id/berita/10331-prof. ritohardoyo:.di.indonesia.backlog.terus.meningkat

Soesilowati, Etty. (2007). Kebijakan Perumahan dan Permukiman Bagi Masyarakat Urban. Jurnal Ekonomi dan Manajemen Dinamika, Vol. 16 No. 1, 2007, pp.105-124.

Stoker, Garry. (1995). The Comparative Study of Urban Regimes, dalam Pierre John. Urban and Regional Policy. The International Library of Comparative Public Policy.

Syarief, Zulfie. (2000). Kebijakan Pemerintah di Bidang Perumahan dan Permukiman bagi Masyarakat Berpendapatan Rendah. Medan: USU Press.

Vuluku, Gayline dan Gachanja, James. (2014). Supply Side Aspects of Residential Housing for Low Income Earners in Kenya. Research in Applied Economics, Vol. 6 No. 3, 2014.

Waziri, A.Garba dan Roosli, Ruhizal. (2013). Housing Policies and Programmes in Nigeria: A Review of the Concept and Implementation. Business Management Dynamics Vol.3, No.2, Aug 2013, pp.60-68.

Wijaya, Ilham M. (2009). Formulasi Atasi Masalah Perumahan di Era Otonomi Daerah (online). Tersedia di http:// riset-properti.blogspot.co.id/2009/02/formulasi-atasi-masalah-perumahan-di.html.

Yantiso, Gebre. (2003). Resettlement and the Unnoticed Losers: Impoverishment Disasters among the Gumz in Ethiopia. Human Organization. Vol. 62 No. 1.

Zandi, Gholamreza; Supramaniam, Mahadevan A/L; Aslam, Ayesha \& Theng, Lai Kin. (2015). The Economical Factors Affecting Residential Property Price:The Case of Penang Island. International Journal of Economics and Finance; Vol. 7, No. 12; 2015. Published by Canadian Center of Science and Education.

Citation: Taufik Hendra Kusuma. "Analysis of Factors Affecting House Ownership in Indonesia" American Research Journal of Business and Management. 2018; 4(1): 1-12.

Copyright (c) 2018 Taufik Hendra Kusuma. This is an open access article distributed under the Creative Commons Attribution License, which permits unrestricted use, distribution, and reproduction in any medium, provided the original work is properly cited.

American Research Journal of Business and Management

Page 12 